\title{
Modulation by IL-10 of Antigen-induced Allergic Responses in Mice
}

\author{
Claudia Zuany-Amorim ${ }^{+}$, B Boris Vargaftig, Marina Pretolani
}

Unité de Pharmacologie Cellulaire, Institut Pasteur, INSERM n 485, 25, rue du Dr. Roux, 75015 Paris, France

Over the last few years, we examined the anti-allergic properties of interleukin (IL)-10 in different models of inflammation in the mouse, as well as against IgE-dependent activation of mouse bone marrow-derived mast cells $(B M M C)$. We showed that IL-10, concurrently administered with ovalbumin, inhibited inflammatory cell accumulation in the airways and in the peritoneal cavity of sensitized mice, as well as the accompanying cytokine release. IL-10 also blocked antigen-induced cytokine generation by IgE-stimulated BMMC. Together, these results identify a novel biological property of IL-10, as a cytokine with potent anti-allergic activities.

Key words: interleukin-10 - eosinophils - mast cells - TNF- $\alpha$ - interleukin-5

Allergic inflammation involves the attraction and activation of a variety of cell types at the site of antigen stimulation, including mast cells, eosinophils, neutrophils and lymphocytes (Arm \& Lee 1992). Attention is particularly focused on eosinophils, since their recruitment in elevated numbers into the airways of asthmatics after allergen exposure (Bousquet et al. 1990, Azzawi et al. 1992) may lead to a long-term damage of the bronchial mucosa (Gleich \& Adolphson 1986), as a result of the release of cytotoxic proteins (Gleich 1990). Several mechanisms responsible for the attraction and localization of inflammatory cells at site of allergic reactions have been proposed. Among them, attention is presently focused on Th2-derived cytokines, particularly interleukin (IL)-5, which promotes the growth, differentiation, survival and activation of eosinophils (Sanderson et al. 1985, Clutterbuck et al. 1989, Sanderson 1992) and IL4, which induces IgE production by B cells (Pene et al. 1988). In murine models of allergic inflammation, infiltration of the airways by eosinophils is regulated by IL- 5 and IL-4, since sensitized mice treated with anti-IL-5 (Nakajima et al. 1992) or anti-IL-4 (Lukacs et al. 1994) antibodies display reduced eosinophilia in their bronchoalveolar lavage (BAL) fluid and bronchial tissue following antigen challenge.

IL-10 was initially characterized as a product of $\mathrm{CD} 4^{+} \mathrm{T}$-lymphocytes of the Th2 subtype and shown to inhibit interferon (IFN)- $\gamma$ prodution by

${ }^{+}$Corresponding author. Fax +33-1-4568.8703. E-mail: czamorim@pasteur.fr

Received 3 September 1997

Accepted 30 September 1997
Th1 clones (Fiorentino et al. 1989). Several properties of IL-10 on various cell types have been described since then, including growth stimulation of thymocytes, mast cells and B cells, and inhibition of cytokine production by activated monocytes, macrophages (Moore et al. 1993) and, more recently, by neutrophils (Cassatella et al. 1993, Kasama et al. 1994) and eosinophils (Takanashi et al. 1994). Only a few studies, however, have focused on the in vivo allergic modulatory properties of IL-10.

In this report, we evaluated the effects of IL10 on: (i) Antigen-induced airway inflammation in immunized BALB/c mice; (ii) IgE-dependent activation of mouse bone marrow-derived mast cells (BMMC); (iii) Antigen-induced IL-5 generation, $\mathrm{CD} 4^{+} \mathrm{T}$-lymphocyte infiltration and activation into the mice peritoneal cavity.

Antigen-induced cellular recruitment into the airways of sensitized mice - The intra-nasal instillation of $10 \mu \mathrm{g}$ ovalbumin to sensitized BALB/c mice induced a rise in the number of eosinophils in the bronchial tissue at $24 \mathrm{hr}$ (Fig. 1A). Treatment with $0.1 \mu \mathrm{g}$ recombinant murine (rm) IL-10, markedly decreased ovalbumin-induced eosinophil infiltration in the peribronchial wall (Fig. 1B), as well as in the BAL fluid (Zuany-Amorim et al. 1995).

Several lines of evidence designate tumor-necrosis factor (TNF)- $\alpha$ as a cytokine generated by numerous cell types during inflammatory reactions and shock states (Tracey \& Cerami 1993). The participation of TNF- $\alpha$ in allergic reactions is linked to different observations, including its release by mast cells, basophils and alveolar macrophages upon IgE-dependent mechanisms (Burd et al. 1989, Gordon \& Galli 1990, Ohno et al. 1990, 


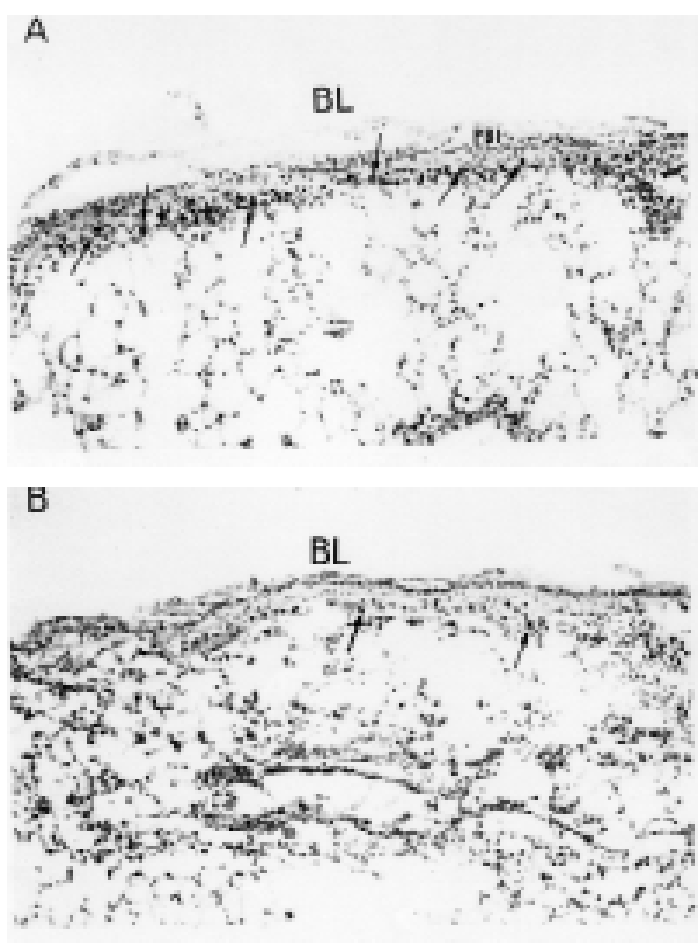

Fig. 1: cyanide-resistant eosinophil peroxidase activity in the bronchial wall of sensitized saline- or antigen-challenged mice. (A) Lung section from an immunized ovalbumin-challenged mouse used $24 \mathrm{hr}$ after the challenge, showing massive eosinophil infiltration concentrated in the bronchial submucosa (arrows); (B) ovalbumin-challenged-rmIL-10 (0.1 $\mu \mathrm{g} / \mathrm{mouse})$ treated mouse with scant eosinophils in the bronchial submucosa (arrows). BL : bronchial lumen, PBI : peribronchial infiltrate. Original magnifications x 100 .

Gosset et al. 1991). High levels of TNF- $\alpha$ have been shown in monocytes and epithelial cells from asthmatics (Mattoli et al. 1991) and BAL fluid from antigen-challenged guinea-pigs (Watson et al. 1993). Finally, treatment of sensitized guinea-pigs with an IL-1 receptor antagonist prevents antigeninduced eosinophil accumulation and TNF- $\alpha$ generation in the BAL fluid (Watson et al. 1993), indicating that TNF- $\alpha$ may modulate allergic airway inflammation. We thus investigated whether antigen challenge induced the release of this cytokine in the BAL fluid of sensitized mice and verified the potential modulatory activity of IL-10 in this process. The intra-nasal administration of ovalbumin was followed by a marked rise in the levels of TNF- $\alpha$ in the BAL fluid, which reached a peak at $1 \mathrm{hr}$ to resolve between 3 and $6 \mathrm{hr}$ after the challenge (Fig. 2A). The simultaneous administration of ovalbumin and rmIL-10 indicated a substantial reduction in the levels of TNF- $\alpha$, particularly at 1 hr (Fig. 2A), a result extending previous observations showing reduction by IL-10 of LPS-induced in vivo TNF- $\alpha$ generation (Howard et al. 1993,
Takanashi et al. 1994). Thus, the observation that TNF- $\alpha$ released upon antigenic stimulation is also susceptible of inhibition by IL-10 may have important consequences for the subsequent invasion of the bronchial wall by inflammatory cells.

Accordingly, failure by IL-10 to modify antigen-induced cellular infiltration when administered $1 \mathrm{hr}$ after the challenge, i.e., the time of the peak release of TNF- $\alpha$ in the BAL fluid, support the hypothesis that blockade of local TNF- $\alpha$ generation and inhibition of leukocyte recruitment are related phenomena. In confirmation, we demonstrate that the local administration of an antiserum to TNF- $\alpha$ markedly reduced antigen-induced eosinophil accumulation in the BAL fluid (Fig. 2B). These results extend those from previous studies showing the participation of TNF- $\alpha$ in leukocyte infiltration associated with IgE-dependent cutaneous inflammation in sensitized mice (Wershil et al. 1991). Together, these results suggest that the inhibitory effect of IL-10 probably involved downregulation of TNF- $\alpha$ generation in the BAL fluid, since treatment of sensitized mice with a specific anti-TNF- $\alpha$ antiserum drastically reduced airway eosinophilia.

IgE-dependent cytokine generation by mast cells - Contrary to the inhibition of allergic airway inflammation observed when rmIL-10 was given by intra-nasal route, its subcutaneous injection did not modify antigen-induced cellular accumulation in the BAL fluid (data not shown). These results suggest that the target(s) for IL-10 are located in the airways and that the amounts of rmIL-10 reaching the bronchial compartment after its systemic administration are probably not sufficient to display an effect. Since mast cells are one of the major sources of TNF- $\alpha$ in the bronchial wall, we hypothesized that reduced TNF- $\alpha$ release observed in the BAL fluid from antigen challenged IL-10treated mice resulted from mast cell deactivation by IL-10. To address this question, we tested the extent to which IL-10 could interfere with IgEmediated in vitro mast cell activation, with particular emphasis to cytokine production.

Dinitrophenyl-bovine serum albumin (DNPBSA)-mediated stimulation of BMMC was followed by TNF- $\alpha$ release, which occurred as early as $1 \mathrm{hr}$ after challenge, peaked at $3 \mathrm{hr}$ and resolved between 6 and $24 \mathrm{hr}$ (Fig. 3A). Incubation of the cells with $50 \mathrm{ng} / \mathrm{ml} \mathrm{rmIL-10} \mathrm{resulted} \mathrm{in} \mathrm{a} \mathrm{signifi-}$ cant inhibition of TNF- $\alpha$ production, particularly at 3 and $6 \mathrm{hr}$ (Fig. 3A). These findings suggest that $\mathrm{TNF}-\alpha$ originating from pulmonary mast cells upon antigenic stimulation is one of the main targets for the anti-allergic activity of IL-10. Northern blot analysis revealed a reduction by rmIL-10 of 


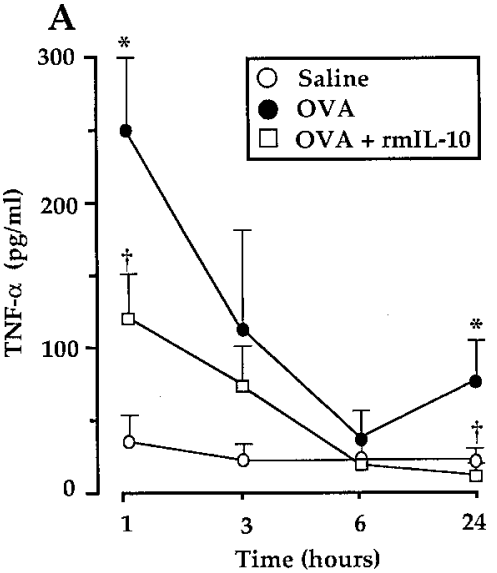

B

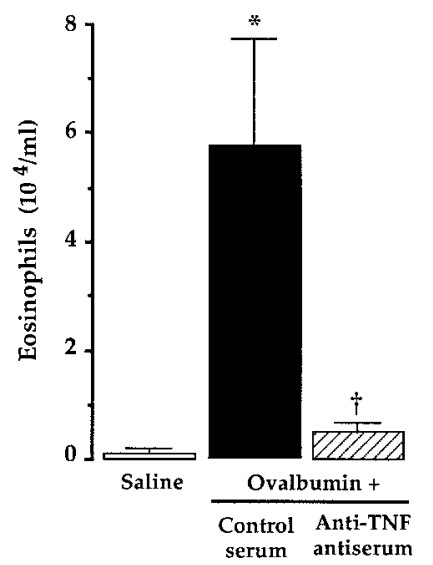

Fig. 2 - A: inhibition by rmIL-10 of antigen-induced TNF- $\alpha$ generation in the BAL fluid from sensitized mice. Sensitized $\mathrm{BALB} / \mathrm{c}$ mice were challenged with intra-nasal saline $(\mathrm{O})$, or with $10 \mu \mathrm{g}$ ovalbumin, administered either alone ( ) or with 0.1 ( $\square$ Mg rmIL-10 and they were killed at various time-intervals after the challenge. The levels of TNF- $\alpha$ in the BAL fluid were evaluated by a double-sandwitch specific ELISA. Results are expressed as means \pm SEM of 5-9 experiments for each group. B: eosinophil distribution in the BAL fluid from sensitized mice challenged with intra-nasal saline $(\square)$ or ovalbumin and treated concomitantly, via the intra-nasal route, with $50 \mu \mathrm{l} /$ mouse of a sheep anti-murine TNF- $\alpha$ antiserum (国) or with its control preimmune serum ( $)$. Results represent the number of eosinophils $\times 10^{4} / \mathrm{ml}$ BAL fluid. $* p<0.05$ and ${ }^{\dagger} p$ $<0.05$, as compared to saline- or ovalbumin-challenged untreated mice, respectively.

TNF- $\alpha$ mRNA expression, a finding consistent with the inhibition of TNF- $\alpha$ protein release (Arock et al. 1995). In contrast, while GM-CSF protein release in the medium was decreased by more than $50 \%$ by $50 \mathrm{ng} / \mathrm{ml}$ of rmIL-10 (Fig. 3B), the same concentration of the cytokine failed to reduce GMCSF mRNA expression (Arock et al. 1995). This suggests that IL-10 interferes rather with post-transcriptional events involved in GM-CSF production than with its gene expression.

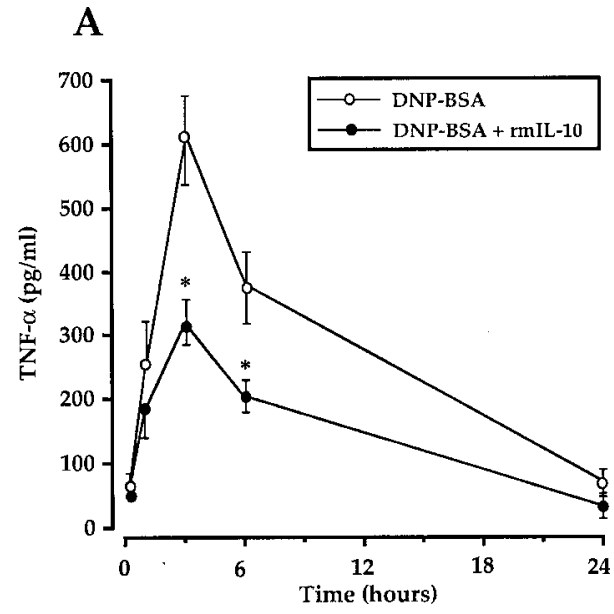

B

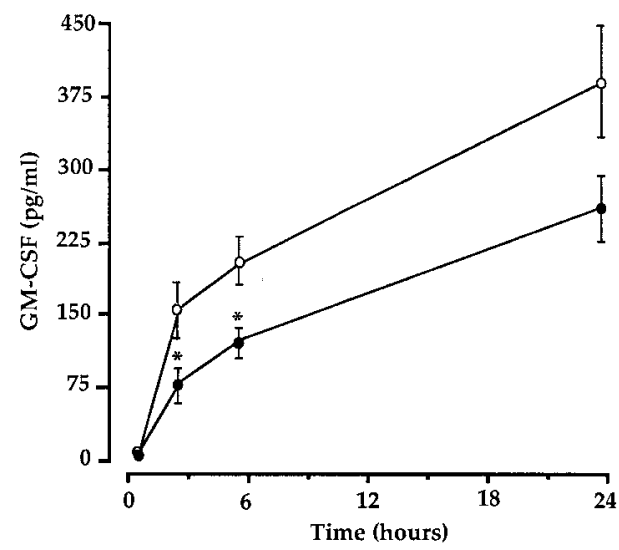

Fig. 3: effect of rmIL-10 on DNP-BSA-induced TNF- $\alpha$ (A) and GM-CSF (B) release from mouse BMMC. IgE-sensitized BMMC were incubated with $50 \mathrm{ng} / \mathrm{ml} \mathrm{rmIL-10(O)} \mathrm{for} 10 \mathrm{~min}$ and then challenged with $10 \mathrm{ng} / 10^{6}$ cells of DNP-BSA ( $\mathrm{O}$ ). The levels of TNF- $\alpha$ and GM-CSF were determined by a specific ELISA. Values are means \pm SEM of 4-8 experiments. ${ }^{*} p$ $<0.05$, as compared with sensitized DNP-BSA-stimulated cells.

Antigen-induced IL-5 generation, $C D 4^{+}$T-lymphocyte and eosinophil infiltration into the mice peritoneal cavity - The i.p. injection of $1 \mu \mathrm{g}$ ovalbumin to sensitized BALB/c mice induced a marked increase in the number of eosinophils, starting at $6 \mathrm{hr}$ and reaching a plateau between 24 and $48 \mathrm{hr}$ (Fig. 4). No changes in the number of eosinophils were observed in saline-challenged mice at any time point (Fig. 4A).

The administration of $0.1 \mu \mathrm{g}$ rmIL-10, concomitantly injected with $1 \mu \mathrm{g}$ ovalbumin, reduced eosinophil counts at $6 \mathrm{~h}$ and $24 \mathrm{hr}$ after the antigen challenge. At $48 \mathrm{hr}$, even though the numbers of eosinophils were reduced by $47 \%$ by the treatment with rmIL-10, the high variability in cell counts precluded the results from achieving statistical significance (Fig. 4A). 

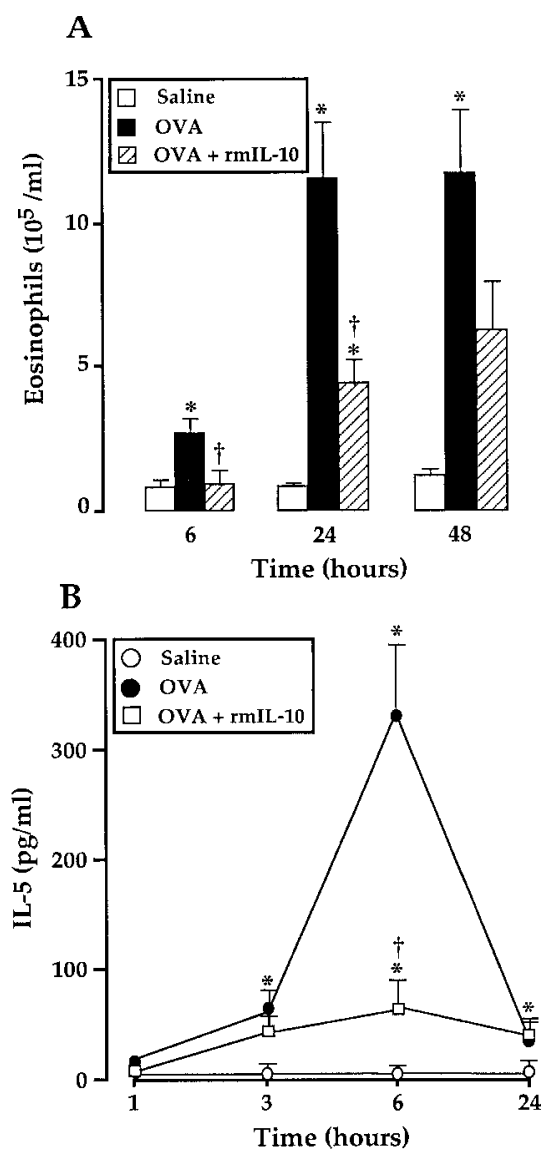

Fig. 4 - A: effect of rmIL-10 on antigen-induced eosinophil accumulation in the PL fluid from sensitized mice killed 6, 24 or $48 \mathrm{hr}$ after the challenge. Animals were injected i.p. either with saline $(\square)$, or with $1 \mu \mathrm{g}$ ovalbumin alone $(\square)$, or mixed with $0.1 \mu \mathrm{g} /$ cavity rmIL-10 (囫). B: inhibition by rmIL-10 of antigen-induced IL-5 release in the PL fluid from sensitized mice. Sensitized mice were challenged with saline $(O)$, or with $1 \mu \mathrm{g}$ ovalbumin alone ( ), or concurrently administered with $0.1 \mu \mathrm{g} \mathrm{rmIL}-10(\square)$ and they were sacrificed at various time intervals after the challenge. The levels of IL-5 in the PL fluid were determined by enzyme immunometric assay. Results are expressed as means \pm SEM (vertical bars) of 3-14 experiments. ${ }^{*} p<0.05$ and $\dagger p<0.05$, as compared to saline- or ovalbuminchallenged untreated mice, respectively.

Contrary to what we have observed when the animals were challenged via the intra-nasal route, no release of TNF- $\alpha$ was detected in the supernatant of peritoneal lavage (PL) fluid after the intraperitoneal administration of ovalbumin, at any time-point (data not shown). These results indicate that IL-10 reduced antigen-induced eosinophilia in the peritoneal cavity by mechanisms unrelated to the blockade of the local generation of TNF- $\alpha$ and suggest that, depending upon the site of inflammation, IL-10 may exhibit anti-allergic properties by acting on different cell types. Interestingly enough, the administration of rmIL-10, $3 \mathrm{hr}$ after antigen challenge still inhibits eosinophilia in the PL fluid at $24 \mathrm{hr}$ (Zuany-Amorim et al. 1996). This result differs from our previous findings showing that the intra-nasal instillation of rmIL-10, $1 \mathrm{hr}$ after ovalbumin stimulation, failed to protect sensitized mice against eosinophil accumulation in the BAL fluid (Zuany-Amorim et al. 1995). This discrepancy suggests that mediator(s) and/or cytokine(s) released in the peritoneal cavity later than $3 \mathrm{hr}$ after ovalbumin stimulation are involved in the eosinophil recruitment and are target for the anti-allergic activity of IL-10. The data presented herein show marked down-regulation by rmIL-10 of antigen-induced IL-5 release in the PL fluid at 6 hr (Fig. 4B), a phenomenon temporally correlated with the subsequent inhibition of eosinophil accumulation in this compartment. The IL-5-dependency of allergic eosinophilia in sensitized mice has been widely demonstrated (Kaneko et al. 1991, Okudaira et al. 1991). In particular, the observation that the in vivo administration of an antibody to murine IL-5 receptor prevented eosinophilia in IL-5 transgenic mice (Hitoshi et al. 1990), further supports the concept that IL-5 generation and eosinophil recruitment are related events. In confirmation of these findings, we showed a reduced antigen-induced eosinophil accumulation in the peritoneal cavity of sensitized mice after treatment with a neutralizing anti-IL-5 monoclonal antibody (Zuany-Amorim et al. 1996).

Ovalbumin stimulation was followed by a timedependent rise in $\mathrm{CD}^{+} \mathrm{T}$ cells at $24 \mathrm{hr}$ (Fig. 5A). In parallel, a significant increment in the number of $\mathrm{CD}^{+}$cells bearing IL-2 receptor on their surface $\left(\mathrm{CD} 25^{+} / \mathrm{CD} 4^{+} \mathrm{T}\right.$-cells) was observed at $24 \mathrm{hr}$ (Fig. 5B). When $0.1 \mu \mathrm{g} \mathrm{rmIL-10}$ were co-injected with ovalbumin, a significant reduction in the number of CD4 ${ }^{+} \mathrm{T}$-lymphocytes and in that of $\mathrm{CD} 25^{+} /$ $\mathrm{CD}^{+}$cells at $24 \mathrm{hr}$ was observed (Fig. 5A, B). These results parallel those of Jinquan et al. (1993), who demonstrated that IL-10 inhibits in vitro $\mathrm{CD}^{+}{ }^{+}$ T-lymphocyte chemotaxis induced by IL- 8 .

Accumulating evidence indicates that the recruitment and function of eosinophils may be orchestrated by the products of activated T-lymphocytes. Thus, our observations that IL- 5 release in the PL fluid rised at $6 \mathrm{hr}$, while T-cell numbers increased at $24 \mathrm{hr}$, suggest that T-lymphocytes residing in the peritoneal cavity, rather than those having infiltrated this compartment in response to antigen challenge, are responsible for the early cytokine release and the accompanying eosinophilia. Alternatively, cell types other than T-lymphocytes, such as mast cells (Plaut et al. 1989), may be involved in ovalbumin-induced IL-5 production at $6 \mathrm{hr}$. Nevertheless, our observation that 

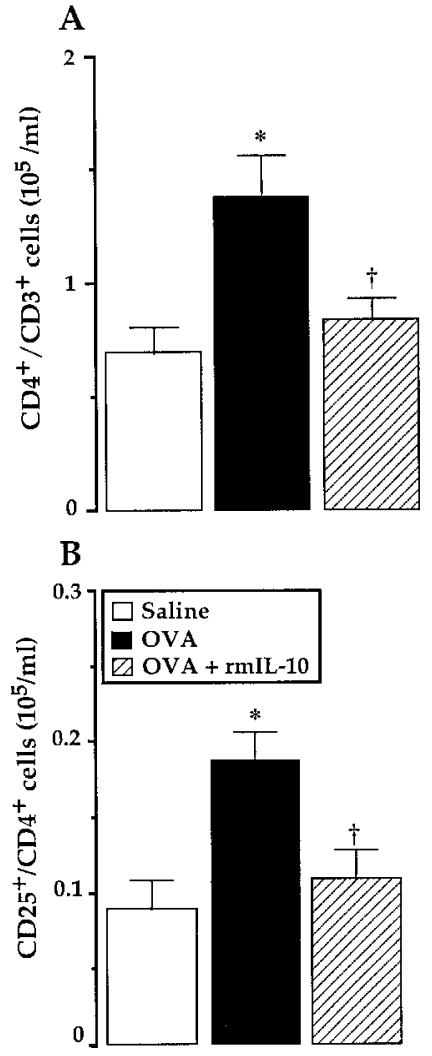

Fig. 5: effect of rmIL- 10 on antigen-induced $\mathrm{CD} 4^{+} / \mathrm{CD}^{+}$and $\mathrm{CD} 25^{+} / \mathrm{CD}^{+} \mathrm{T}$ cell accumulation in the PL fluid from sensitized mice killed $24 \mathrm{hR}$ after the challenge. Animals were injected i.p. either with saline $(\square)$, or with $1 \mu$ g ovalbumin alone (ロ), or mixed with $0.1 \mu \mathrm{g} /$ cavity rmIL-10 (圈). Results are expressed as means \pm SEM (vertical bars) of 5-11 experiments. ${ }^{*} p<0.05$ and $\dagger p<0.05$, as compared to saline- or ovalbuminchallenged untreated mice, respectively.

specific depletion of CD4+ $4^{+}$-lymphocytes abolished both eosinophil accumulation and IL-5 release in the peritoneal cavity (Zuany-Amorim et al. 1996) suggests that IL-5 originating from Tcells plays an important role in antigen-induced eosinophilia in this model.

To verify whether IL-10 would directly interfere with T-cell activation, we triggered in vitro and in vivo the $\mathrm{CD} 3 /$ Tcell receptor complex with an anti-CD3 mAb (Hirsch et al. 1989). In vivo stimulation of non immunized mice with anti-CD3 $\mathrm{mAb}$ led to a time-dependent production of IL-5 in the PL fluid, which was not modified by treatment of the animals with a dose of rmIL-10 effective against ovalbumin-induced eosinophilia and IL-5 release. In parallel, IL-10 failed to inhibit CD3-dependent IL-5 generation from purified spleen $\mathrm{CD}^{+}{ }^{+} \mathrm{T}$-lymphocytes (Zuany-Amorim et al. 1996). These findings suggest that mechanisms unrelated to T-cell activation (possibly antigenpresenting cell deactivation) are targets for the antiallergic activity of IL-10 in this model.

In recent years, evidence has suggested that allergic inflammation is a Th2-cytokine-mediated disease. As IL-10 is produced by bronchial epithelial cells (Bonfield et al. 1995) and can suppress acute inflammation induced by immune-complexes in mice lungs (Shanley et al. 1995), there has been considerable interest in the role of IL-10 in regulating Th2-like responses leading to allergic lung inflammation. Our present results showing that IL10 can negatively regulate allergic inflammatory reaction by inhibiting IL- 5 and TNF- $\alpha$ release, suggest that this cytokine may have therapeutic value for treating eosinophilic disorders, such as bronchial asthma.

\section{REFERENCES}

Arm JP, Lee TH 1992. The pathobiology of bronchial asthma. Adv Immunol 51: 323-382.

Arock M, Zuany-Amorim C, Singer M, Benhamou M, Pretolani M 1995. Interleukin-10 inhibits mast cell activation. Eur J Immunol 26: 166-172.

Azzawi M, Johnston S, Majumdar S, Kay AB, Jeffery PK 1992. T lymphocytes and activated eosinophils in airway mucosa in fatal asthma and cystic fibrosis. Am Rev Respir Dis 145: 1477-1486.

Bonfield TL, Konstan MW, Burfeind JR, Panuska JB, Hilliard JB, Berger M 1995. Normal bronchial epithelial cells constitutively produce the anti-inflammatory cytokine interleukin-10, which is downregulated in cystic fibrosis. Am J Respir Cell Mol Biol 13: 257-261.

Bousquet J, Chanez P, Lacoste JY, Barneron G, Ghavanian N, Enander I, Venge P, Ahlstedt S, Simony LJ, Godard P, Michel FB 1990. Eosinophilic inflammation in asthma. N Engl J Med 323: 10331039.

Burd PR, Rogers HW, Gordon JR, Martin CA, Jayaraman S, Wilson SD, Dvorak AM, Galli SJ, Dorf ME 1989. Interleukin-3-dependent and -independent mast cells stimulated with IgE and antigen express multiple cytokines. J Exp Med 170: 245-257.

Cassatella MA, Meda L, Bonora S, Ceska M, Constantin G 1993. Interleukin-10 (IL-10) inhibits the release of proinflammatory cytokines from human polymorphonuclear leukocytes. Evidence for an autocrine role of tumor necrosis factor and IL- $1 \beta$ in mediating the production of IL- 8 triggered by lipopolysaccharide. J Exp Med 178: 2207-2211.

Clutterbuck EJ, Hirst EM, Sanderson CJ 1989. Human interleukin-5 (IL-5) regulates the production of eosinophils in human bone marrow cultures: comparison and interaction with IL-1, IL-3, IL-6, and GMCSF. Blood 73: 1504-1512.

Fiorentino DF, Bond MW, Mosmann TR 1989. Two types of mouse T helper cells: IV. Th2 clones secrete a factor that inhibits cytokine production by Th1 clones. J Exp Med 170: 2081-2095.

Gleich GJ, Adolphson CR 1986. The eosinophilic leu- 
kocyte: Structure and function. Adv Immunol 39: 177-183.

Gleich GJ 1990. The eosinophil and bronchial asthma: current understanding. J Allergy Clin Immunol 85: 422-427.

Gordon JR, Galli SJ 1990. Mast cells as a source of both preformed and immunologically inducible TNF- $\alpha /$ cachectin. Nature 346: 274-276.

Gosset P, Tsicopoulos M, Wallaert B, Vannimenus C, Joseph M, Tonnel AB, Capron A 1991. Increased secretion of tumor necrosis factor a and interleukin6 from alveolar macrophages consecutive to the development of the late asthmatic reaction. $J$ Allergy Clin Immunol 88: 561-571.

Hirsch R, Gress RE, Pluznik DH, Eckhaus M, Bluestone JA 1989. Effects of in vivo administration of antiCD3 monoclonal antibody on $\mathrm{T}$ cell function in mice. II. In vivo activation of T cells. J Immunol 142: 737 743.

Hitoshi Y, Yamaguchi N, Korenaga M, Mita S, Tominaga A, Takatsu K 1990. In vivo administration of antibody to murine IL-5 receptor inhibits eosinophilia of IL-5 transgenic mice. Int Immunol 3: 135-139.

Howard M, Muchamuel T, Andrade S, Menon S 1993. Interleukin 10 protects mice from lethal endotoxemia. J Exp Med 177: 1205-1208.

Jinquan T, Larsen CG, Gesser B, Matsushima K, Thestrup-Pedersen K 1993. Human IL-10 is a chemoattractant for $\mathrm{CD}^{+} \mathrm{T}$ lymphocyte and an inhibitor of IL-8-induced CD4 ${ }^{+}$T lymphocyte migration. J Immunol 151: 4545-4551.

Kaneko M, Hitoshi Y, Takatsu K, Matsumoto S 1991. Role of interleukin-5 in local accumulation of eosinophils in mouse allergic peritonitis. Int Arch Allergy Appl Immunol 96: 41-45.

Kasama T, Strieter RM, Lukacs NW, Burdick MD, Kunkel SL 1994. Regulation of neutrophil-derived chemokine expression by IL-10. J Immunol 152: 3559-3569.

Lukacs WN, Strieter RM, Chensue SW, Kunkel SL 1994. Interleukin-4-dependent pulmonary eosinophil infiltration in a murine model of asthma. Am J Respir Cell Mol Biol 10: 526-532.

Mattoli S, Mattoso VL, Soloperto M, Allegra L, Fasoli A 1991. Cellular and biochemical characteristics of bronchoalveolar lavage fluid in symptomatic nonallergic asthma. J Allergy Clin Immunol 87: 794802.

Moore KW, O'Garra A, de Waal Malefyt R, Vieira P, Mosmann TR 1993. Interleukin-10. Annu Rev Immunol 11: 165-190.

Nakajima H, Iwamoto I, Tomoe S, Matsumura R, Tomioka H, Takatsu K, Yoshida S 1992. CD4 ${ }^{+}$Tlymphocytes and interleukin-5 mediate antigen-induced eosinophil infiltration into the mouse trachea. Am Rev Respir Dis 146: 374-377.

Ohno I, Yamaguchi K, Takasihima T 1990. Gene expression and production of tumor necrosis factor by a rat basophilic cell line (RBL-2H3) with IgE recep- tor triggering. Immunology 70: 88-93.

Okudaira H, Matsuzaki M, Dohl G, Suko M, Kasuya M, Takatsu K 1991. T-cell-dependent accumulation of eosinophils in the lung and its inhibition by monoclonal anti-interleukin-5. Int Arch Allergy Appl Immunol 199: 171-173.

Pene J, Rousset F, Brière F, Chrétien I, Bonnefoy JY, Spits HT, Yokota N, Arai KI, Banchereau J, de Vries JE 1988. IgE production by human B cells is induced by IL- 4 and suppressed by interferons $\gamma$ and $\alpha$ and prostaglandin E2. Proc Natl Acad Sci USA 85: 6880-6884.

Plaut M, Pierce JH, Watson CJ, Hamley-Hyde J, Nordan RP, Paul WE 1989. Mast cell lines produce lymphokines in response to cross-linkage of FceRI or to calcium ionophores. Nature 339: 64-67

Sanderson CJ, Warren DJ, Strath M 1985. Identification of a lymphokine that stimulates eosinophil differentiation in vitro. Its relationship to IL-3 and functional properties of eosinophils produced in cultures. J Exp Med 162: 60-74.

Sanderson CJ 1992. Interleukin-5, eosinophils, and disease. Blood 79: 3101-3109.

Shanley TP, Schmal H, Friedl HP, Ward P 1995. Regulatory effects of intrinsic IL-10 in IgG in immune complex-induced lung injury. J Immunol 154: 34543460.

Takanashi S, Nonaka R, Xing Z, O’Byrne P, Dolovich J, Jordana M 1994. Interleukin 10 inhibits lipopolysaccharide-induced survival and cytokine production by human peripheral blood eosinophils. J Exp Med 180: 711-715.

Tracey KJ, Cerami A 1993. Tumor necrosis factor, other cytokines and disease. Annu Rev Cell Biol 9: $317-$ 343.

Watson ML, Smith D, Bourne AD, Thompson RC, Westwick J 1993. Cytokines contribute to airway dysfunction in antigen-challenged guinea-pigs: inhibition of airway hyperreactivity, pulmonary eosinophil accumulation, and tumor necrosis factor generation by pretreatment with an interleukin-1 receptor antagonist. Am J Respir Cell Mol Biol 8: 365369.

Wershil BK, Wang Z, Gordon JR, Galli SJ 1991. Recruitment of neutrophils during IgE-dependent cutaneous late phase responses in the mouse is mast cell dependent: partial inhibition of the reaction with antiserum against tumor necrosis factor-alpha. J Clin Invest 87: 446-453.

Zuany-Amorim C, Hailé S, Leduc D, Dumarey C, Huerre M, Vargaftig BB, Pretolani M 1995. Interleukin-10 inhibits antigen-induced cellular recruitment into the airways of sensitized mice. J Clin Invest 95: 26442650.

Zuany-Amorim C, Creminon C, Nevers MC, Nahori MA, Vargaftig BB, Pretolani M 1996. Modulation by IL- 10 of antigen-induced IL- 5 generation, CD4 ${ }^{+}$ T-lymphocyte and eosinophil infiltration into the mice peritoneal cavity. J Immunol 157: 377-384. 